Drugs and Driving

\section{When Science and Policy Don't Mix}

\author{
Mark Asbridge, $\mathrm{PhD}$
}

\section{ABSTRACT}

This commentary briefly looks at the Canadian federal government's proposed legislation to strengthen the enforcement of drug-impaired driving, placing special emphasis on cannabis. After outlining the legislation, three issues are examined. Of primary concern is at what level cannabis use impairs driving ability leading to an increased risk of motor vehicle collision. Current epidemiological evidence is reviewed. Equally important is the government's emphasis on the training and implementation of Drug Recognition Experts (DREs), specially trained police officers whose role is to detect drivers under the influence of drugs. Research on the effectiveness of DREs is discussed, along with a dialogue regarding the potential shortcomings of the DRE program. Finally, a brief surveillance of international policy literature on drugs and driving is offered, along with some sober thoughts on the potential difficulties that may emerge in the enforcement of the proposed legislation.

MeSH terms: Cannabis; motor vehicles; public policy; police

\section{RÉSUMÉ}

Il est question, dans ce commentaire, du projet de loi du gouvernement fédéral canadien visant à renforcer les sanctions contre la conduite avec facultés affaiblies par les drogues, et en particulier le cannabis. Après avoir décrit le projet de loi, les auteurs examinent trois enjeux. Tout d'abord, il est important de déterminer le niveau de consommation de cannabis qui affaiblit l'aptitude à conduire et fait augmenter le risque d'accident de la route; les preuves épidémiologiques actuelles sont examinées. Un autre enjeu tout aussi important est l'accent du gouvernement sur la formation et le déploiement d'experts en reconnaissance de drogues (ERD), des policiers ayant reçu un entraînement spécial et dont le rôle est de déceler les conducteurs sous l'emprise des drogues. Les études de recherche sur l'efficacité des ERD sont présentées, ainsi qu'un dialogue sur les carences éventuelles d'un programme d'ERD. Enfin, les auteurs donnent un bref aperçu des publications internationales sur les politiques contre l'intoxication au volant et font quelques réflexions objectives sur les obstacles possibles à l'exécution de la loi proposée.

Department of Community Health and Epidemiology, Dalhousie University, Halifax, NS

Correspondence and reprint requests: Mark Asbridge, Department of Community Health and Epidemiology, Dalhousie University, 5790 University Avenue, Halifax, NS B3H 1V7, Tel: 902-4943761, Fax: 902-494-1597, E-mail: Mark.Asbridge@dal.ca

Acknowledgement: I would like to acknowledge the helpful comments of Robert Solomon, and the editor and reviewers at $\mathrm{CJPH}$, on earlier versions of this commentary.
$\mathrm{O}$ n November 1, 2004, the federal government tabled "New Measures to Strengthen Enforcement of Drug-Impaired Driving". The proposed legislation included \$6.9 million in new funding to strengthen the investigation of drug-impaired driving and improve public health and road safety. As then Deputy Prime Minister and Minister of Public Safety and Emergency Preparedness, Anne McLellan, noted: “Today's announcement reinforces the Government of Canada's commitment to give police the tools they need to detect and deter drug-impaired driving in Canada....The funds we have committed with this bill will go a long way to making our roads and communities safer." ${ }^{1}$ The crux of the proposed legislation is the funding and training of Drug Recognition Experts (DRE), specially trained police who employ a standardized protocol to identify the presence of drugs in suspected motorists.

While changes to the proposed legislation are expected with the new federal government, any re-tabled legislation is likely to be similarly structured and, as such, should be viewed with the same caution. To date, debate on drug-impaired driving continues with regard to: 1) at what level drugs impair the functions necessary for safe driving; 2) whether drivers under the influence of drugs are at an increased risk of motor vehicle collision and injury; and 3) the effectiveness of DREs in identifying drug impairment in motorists. The purpose of this commentary is to briefly critique the federal government's proposed legislation, placing special emphasis on cannabis.

\section{Cannabis impairment and collision risk in the context of driving}

A quick review of published reports leaves little doubt that the prevalence of driving under the influence of cannabis is on the rise in Canada. ${ }^{2-4}$ Recent figures from the 2004 Canadian Addictions Survey suggest that $4 \%$ of the population have driven under the influence of cannabis in the past year, up from $1.5 \%$ in 2003, with substantially higher rates among young people. ${ }^{5}$ Moreover, drugs other than alcohol have increasingly been detected in the bodily fluids of hospitalized and fatally injured drivers. ${ }^{6,7}$ Collectively, this evidence paints a persuasive picture of a Canadian popula- 
tion increasingly involved in driving under the influence of cannabis. Yet a more fundamental question remains unanswered: at what level does cannabis use actually impair driving ability and increase the risk of motor vehicle collision?

The primary psychoactive component in cannabis is THC ( $\Delta^{9}$ tetrahydrocannabinol), which typically produces euphoria, relaxation, and changes in perception at low doses; at higher doses, it produces deficits in attention span and memory, and pain relief. Laboratory research employing driving simulators has noted that at elevated doses, cannabis may produce impairment in the motor and perceptual skills that are necessary for safe driving. ${ }^{8-10}$ Studies of drivers conducted on road courses have uncovered similar results. ${ }^{11}$ Higher doses of cannabis have been associated with impairment in the performance of various functions connected with safe driving of a vehicle. ${ }^{10,12-14}$ Despite this evidence, there remains no clear scientific "minimum" threshold for demonstrating cannabis impairment, nor is there a clear dose-response relationship between cannabis consumption and its effects on the body as it relates to driving ability. ${ }^{15,16}$

A lack of consensus also exists when epidemiological research is considered. While some studies find that cannabis consumption prior to driving increases the risk of collision, ${ }^{17,18}$ this is not true for all studies. ${ }^{14,19-23}$ In fact, some studies suggest that those driving under the influence of cannabis may be less at risk for collision or injury compared to drug-free drivers. ${ }^{11,24,25}$ This lack of consensus in epidemiological studies is complicated by three issues: first, most collision studies fail to include a proper control group of motorists not involved in collisions who have been randomly stopped and tested for drug use. ${ }^{14,26}$ Second, there are concerns with the measurement of cannabis in the urine or blood of motorists. Many studies have only measured inactive THC metabolites, which can linger in the body for weeks after consumption and have no clear relationship to a motorist's impairment and ability to drive. ${ }^{13,14}$ Researchers must employ technologies that measure and isolate active THC metabolites in the whole blood of drivers using advanced equipment (i.e., Gas Chromatography-Mass Spectrometry). This would permit the observation of recent cannabis use in the context of driving. ${ }^{13,19,27}$ Finally, the high prevalence of drug-impaired motorists who also test positive for elevated blood alcohol levels further confounds findings. ${ }^{28,29}$ As Robbe $^{11}$ (p.55) has concluded, "the independent contribution of cannabis to traffic accident causality, particularly in concentrations which are likely to be found in most users, is still dubious." Future studies, involving stronger research designs, are required to fully assess this question. ${ }^{11,20}$

\section{The Drug Recognition Expert (DRE)}

Considerable federal funding has been earmarked for the training of drug recognition experts. DREs are police officers who are specially trained to identify drug impairment in suspected drugged-drivers. DREs employ a procedure that relies on visual recognition of motorists' drug use through the observation of sociobehavioural cues, biological and vital signs, and direct questioning. From this information, the DRE forms an opinion as to whether the suspect is impaired by drugs and which family of drugs are responsible (i.e., stimulants, hallucinogens, analgesics, etc.). Under the proposed legislation, suspected impaired motorists are first given a Standardized Field Sobriety Test, similar to the test for alcohol impairment. If a motorists fails the Sobriety Test but is not impaired by alcohol, they are evaluated (either at the roadside or station) by a DRE. If the DRE suspects drug use, then a fluid sample (blood or urine) is taken for testing to confirm the DRE's suspicion. ${ }^{1}$

The DRE program was created by the Los Angeles Police Department in the late $1970 s^{30}$ and is now used in a number of US States, as well as Australia, New Zealand, Germany, Norway, and Sweden. The program has been in place in Canada since 1995 and is used in Manitoba, Alberta, British Columbia, Ontario, Quebec, and Nova Scotia. Overall, evaluations of the DRE program have generally demonstrated its reliability, identifying motorists under the influence of drugs about 75 to $90 \%$ of the time. ${ }^{31-36}$

While the demonstrated reliability of the DRE program is positive, key concerns remain. First, DREs appear better at identifying certain drugs and drug use among motorists who have consumed a higher drug dosage, yet less apparent is how
DREs perform in evaluating the typical motorists who consume lower drug quantities prior to driving. ${ }^{37}$ Second, most DRE evaluations have been done in a laboratory setting, which does not accurately reflect the circumstances associated with evaluating suspected drug-impaired motorists at the roadside. Third, based on pharmacokinetics (i.e., drug half-life), the time between the roadside stop of a suspected motorist and the testing of fluids for drug metabolites at the station may hinder DREs' efforts to determine drug use in association with driving.

It is understandable why the DRE program is seen as a useful tool. Currently, it is the only viable roadside test for drug use among motorists, as saliva and sweat testing methods remain in development. ${ }^{14}$ It would be beneficial, however, if further evaluative studies of the DRE program were completed, employing randomized trials, performed in the field rather than laboratory, and published in peer-reviewed journals. Greater effort is required by the federal government to look into the legal history of the DRE program in other jurisdictions, while exploring the potential shortcomings of such a program from a scientific and legal standpoint.

\section{Sober summary}

The above critique raises a number of red flags concerning the proposed drugs and driving legislation, the ability of police and RCMP officers to properly enforce drugs and driving legislation, and the ability of crown attorneys to successfully prosecute motorists suspected of driving under the influence of drugs.

What is more surprising is that this information is not new to the Federal Government. As the Canadian Senate Special Committee on Illicit Drugs ${ }^{38}$ has noted, as well as the UK Department of Transport ${ }^{15}$ and the WHO, ${ }^{39}$ cannabis alone, particularly at low doses, appears to have little effect on the skills necessary for safe driving. A quick surveillance of these international reports ${ }^{15,16,40}$ from Germany, Austria, Belgium, England, Switzerland, and other nations, would have revealed many of the concerns raised in this critique. Even less clear are the effects of drugs other than cannabis on driving ability and road safety. In fact, even the "Backgrounder" for the Federal 
Government's media release regarding the proposed legislation noted:

"Unlike alcohol, for the vast majority of drugs, there is no scientific consensus on the threshold drug concentration level in the body that causes impairment and makes driving hazardous. Technology to detect drug concentration at roadside is neither an available nor effective option."

As currently constituted, the proposed federal legislation will make the charging, prosecution, and conviction of suspected drug-impaired drivers, under section 253 of the Canadian Criminal Code, challenging. The Criminal Code necessitates proof of drug impairment in motorists, not merely drug use. Determining minimum thresholds for drug impairment in the context of driving is difficult. Too many variations exist in the individual (drug metabolism, consumption patterns, biological determinants), the drug (drug class, quantity consumed, combination of drugs consumed at one time), the type of drug testing performed, and time lapses between roadside police stop and drug test. Nevertheless, the science on the issue is currently as good as it gets. With time, emerging research on drugs and driving will offer clearer evidence to support and implement more effective, sound, and enforceable legislation, resulting in the improved public health of Canadians.

\section{REFERENCES}

1. Department of Justice Canada. New Measures to Strengthen Enforcement of Drug Impaired Driving. Ottawa, ON: Department of Justice Canada, 2004.

2. Walsh GW, Mann RE. On the high road: Driving under the influence of cannabis in Ontario. Can J Public Health 1999:90(4):260-63.

3. Beirness DJ, Simpson HM, Desmond K. The Road Safety Monitor 2003: Drinking and Driving. Ottawa, ON: Traffic Injury Research Foundation, 2003.

4. Adlaf EM, Mann RE, Paglia A. Drinking, cannabis use and driving among Ontario students. CMAJ 2003;168(5):565-66

5. Asbridge MA, Poulin C, Donato A. Motor vehicle collision risk and driving under the influence of cannabis: Evidence from adolescents in Atlantic Canada. Accid Anal Prev 2005;37:102534.

6. Stoduto G, Vingilis E, Kapur BM, Sheu WJ, McLellan BA, Libanx CB. Alcohol and drug use among motor vehicle collision victims admitted to a regional trauma unit: Demographic, injury, and crash characteristic. Accid Anal Prev 1993;25(4):411-20.

7. Dussault C, Brault M, Bouchard J, Lemire AM. The contribution of alcohol and other drugs among fatally injured drivers in Quebec: Some preliminary results. In: Mayhew DR, Dussault C (Eds.), Proceedings of the 16th International
Conference on Alcohol, Drugs and Traffic Safety. Quebec: Société de l'Assurance Automobile du Québec, 2002;423-30.

8. Liguori A, Gatto CP, Robinson JH. Effects of marijuana on equilibrium, psychomotor performance, and simulated driving. Behav Pharmacol 1998;9:599-609.

9. Low $M$, Klonoff $H$, Marcus A. Neuropsychological effects of marijuana. CMAJ 1973;108(20):157-64.

10. Moskowitz H. Marihuana and driving. Accid Anal Prev 1985;17(4):323-45.

11. Robbe HWJ, O'Hanlon JF. Marijuana and actual driving performance, Report No. DOT HS 808078. U.S. Department of Transportation, National Highway Traffic Safety Administration, Washington, DC, 1993.

12. Berghaus G, Guo BL. Medicines and driver fitness - findings from a meta-analysis of experimental studies as basic information to patients, physicians, and experts. In: Koedan CN, McLean AJ (Eds.), Alcohol, Drugs, and Traffic SafetyT'95: Proceedings for the 13th International Conference on Alcohol, Drugs, and Traffic Safety. Adelaide, Australia, 1995;295-300.

13. Ramaekers JG, Berghaus G, van Laar M, Drummer OH. Dose related risk of motor vehicle crashes after cannabis use. Drug Alcohol Depend 2004;73(2):109-19.

14. Kalant $\mathrm{H}$. Adverse effects of cannabis on health: An update of the literature since 1996. Prog Neuropsychopharmacol Biol Psychiatry 2004;84963

15. UK Department of Transport. Cannabis and driving: A review of the literature and commentary (No.12). London: Department of Transportation, 2000.

16. International Council on Alcohol, Drugs and Traffic Safety. ICADTS Working Group on Illegal Drugs and Driving. May, 2000.

17. Drummer OH, Gerostamoulos J, Batziris H, Chu M, Caplehorn J, Robertson MD, Swann P. The involvement of drugs in drivers of motor vehicles killed in Australian road traffic crashes. Accid Anal Prev 2004;36:239-48.

18. Blows S, Ivers RQ, Connor J, Ameratunga S, Woodward M, Norton R. Marijuana use and car crash injury. Addiction 2005;100:605-11.

19. Bates MN, Blakely TA. Role of cannabis in motor vehicle crashes. Epidemiol Rev 1999;21(2):222-32.

20. Movig KLL, Mathijssen MPM, Nagel PHA, van Egmond T, de Gier JJ, Leufkens HGM, Egberts ACG. Psychoactive substance use and the risk of motor vehicle accidents. Accid Anal Prev 2004;36(4):631-36.

21. Terhune KW. An evaluation of responsibility analysis for assessing alcohol and drug crash effects. Accid Anal Prev 1983;15(3):237-46.

22. Logan MC, Hunter CE, Lokan RJ, White JM, White MA. The Prevalence of Alcohol, Cannabinoids, Benzodiazepines and Stimulants Amongst Injured Drivers and Their Role in Driver Culpability: Part II: The Relationship Between Drug Prevalence and Drug Concentration, and Driver Culpability. Accid Anal Prev 2000;32(5):623-32.

23. Waller PF, Blow FC, Maio RF, Singer K, Hill EM, Schaefer N. Crash characteristics and injuries of victims impaired by alcohol versus illicit drugs. Accid Anal Prev 1997;29(6):817-27.

24. Terhune $\mathrm{K}$. The incidence and role of drugs in fatally injured drivers. NHTSA. Technical Report DOT HS 808 065. Washington: US Department of Transportation, 1992.

25. Sexton BF, Tunbridge RJ, Brooke-Carter N, Jackson PG, Wright K, Stark MM, Englehart K. The Influence of Cannabis on Driving. Prepared for Road Safety Division, Department of the Environment, Transport and the Regions, UK, by Transport Research Laboratory, Ltd., TRL Report 477, 2000.

26. Macdonald S, Anglin-Bodrug K, Mann RE, Erickson P, Hathaway A, Chipman C, Rylett M. Injury risk associated with cannabis and cocaine use. Drug Alcohol Depend 2003;72(2):99-115.

27. Begg DJ, Langley JD, Stephenson S. Identifying factors that predict persistent driving after drinking, unsafe driving after drinking, and driving after using cannabis among young adults. Accid Anal Prev 2003;35(5):669-75.

28. Perez-Reyes M, Hicks RE, Bumberry J, Jeffcoat $\mathrm{AR}$, Cook EE. Interaction between marihuana and ethanol: Effects on psychomotor performance. Alcohol Clin Exp Res 1988;12(2):268-76.

29. Cimbura G, Lucas DM, Bennett RC, Donelson AC. Incidence and toxicological aspects of cannabis and ethanol detected in 1394 fatally injured drivers and pedestrians in Ontario (19821984). J Forensic Sci 1990;35(5):1035-41.

30. Page TE. The Drug Recognition Expert (DRE) Response to the Drug Impaired Driver: An Overview of the DRE Program, Officer, and Procedures. Los Angeles, CA: Los Angeles Police Department Drug Recognition Unit, 1998. Available online at: www.cityofla.org/LAPD/ traffic/dre/drgdrvr.htm (Accessed November 26, 2004).

31. Bigelow GE, Bickel WE, Roache JD, Liebson IA, Nowowieski P. Identifying types of drug intoxication: Laboratory evaluation of a subjectexamination procedure. NHTSA Technical Report DOT HS 806 753. Washington: US Department of Transportation, 1985.

32. Compton RP. Field evaluation of the Los Angeles Police Department drug detection procedure. NHTSA Technical Report DOT HS 807012. Washington: US Department of Transportation, 1986.

33. Preusser DF, Ulmer RG, Preusser CW. Evaluation of the impact of the Drug Evaluation and Classification programme on enforcement and adjudication. NHTSA Technical Report DOT HS 808 058. Washington: US Department of Transportation, 1992.

34. Adler EV, Burns M. Drug Recognition Expert (DRE) Validation Study. Final Report to Governor's Office of Highway Safety. Arizona Department of Public Safety, 1994.

35. Shinar D, Schechtman E, Compton RP. Signs and symptoms predictive of drug impairment. In: 15th International Conference on Alcohol, Drugs \& Traffic Safety. Stockholm, Sweden: International Council on Alcohol, Drugs \& Traffic Safety, 2000.

36. Smith JA, Hayes CE, Yolton RL, Rutledge DA, Citek K. Drug recognition expert evaluations made using limited data. Forensic Sci Int 2002;130:167-73.

37. Shinar D, Schechtman E. Drug identification performance on the basis of observable signs and symptoms. Accid Anal Prev 2005;37:843-51.

38. Canadian Senate Special Committee on Illegal Drugs. Cannabis: Summary Report: Our Position for a Canadian Public Policy. Ottawa: September, 2002.

39. World Health Organization. World Report on Road Traffic Injury Prevention. Peden $M$, Scurfield R, Sleet D, Mohan D, Hyder A, Jarawan E, Mathers C (Eds.). Geneva: World Health Organization, 2004.

40. European Monitoring Centre for Drugs and Drug Addiction. Literature review on the relation between drug use, impaired driving and traffic accidents, Publication no. CT.97.EP.14. Lisbon, Portugal: EMCDDA, 1999.

Received: April 18, 2005

Accepted: January 27, 2006 